\title{
Senyawa Metabolit Sekunder dan Aspek Farmakologi Alocasia macrorrhizos
}

\author{
Yuliana; Sri Fatmawati* \\ Departemen Kimia, Fakultas IImu Alam, Institut Teknologi Sepuluh Nopember, ITS. Kampus \\ ITS Sukolilo - Surabaya, Indonesia. \\ *E-mail: fatma@chem.its.ac.id
}

\begin{abstract}
Alocasia macrorrhizos or sente hijau is a traditional medicinal plant in Celebes - Indonesia. The secondary metabolite compounds have been isolated from the root, rhizome, and leaves of the plant. From the root part, aloceramide compounds have been isolated, whereas rhizome contain lignanamide, monoindole, indole, and piperidine compounds, while leaves have triglochinin and isotriglochinin components. Furthermore, the plant also has biological activities such as antidiuretic, anticancer, antioxidant, antimicrobial, antidiabetic, antihyperglycemia and others. This review aims for integrating the secondary metabolite compounds and the biological activity of A. macrorrhizos, as well as for providing scientific evidences which is needed for further the plant's investigation.
\end{abstract}

Keywords: Jamu, Indonesian traditional medicines, Alocasia, chemical constituents

\begin{abstract}
Alocasia macrorrhizos atau sente hijau merupakan tanaman obat tradisional di daerah Sulawesi Indonesia. Beberapa Senyawa metabolit sekunder telah diisolasi dari akar, rimpang dan daun tanaman tersebut. Bagian akar mengandung senyawa aloceramida, rimpang mengandung senyawa lignanamida, monoindol, indol dan piperidin, serta daun mengandung triglochinin dan isotriglochinin. Selain itu, A. macrorrhizos juga memiliki aktivitas biologis seperti antidiuretik, antikanker, antioksidan, antimikroba, antidiabetes, antihipergikemik dan lain-lain. Review ini bertujuan untuk mengintegrasikan senyawa metabolit sekunder dan aktivitas biologis dari A. macrorrhizos, sekaligus memberikan bukti ilmiah yang diperlukan pada penelitian lebih lanjut dari A. macrorrhizos.
\end{abstract}

Kata kunci: Jamu, obat tradisional Indonesia, Alocasia, konstituen kimia

DOI: http://dx.doi.org/10.12962/j25493736.v3i1.3494 


\section{Pendahuluan}

Alocasia merupakan salah satu spesies talas yang memiliki lateks atau bergetah. Tanaman dari genus ini biasanya digunakan sebagai obat tradisional [1]. Salah satu jenisnya yaitu Alocasia macrorrhizos [2] (Gambar 1). A. macrorrhizos memiliki sinonim yaitu $A$. indica atau A. macrorrhiza [3] yang dikenal sebagai sente hijau di Indonesia, dimana juga disebut dalam bahasa daerah sebagai Lawira di Sulawesi Selatan, Talas sente di Pulau Jawa [4]. Di negara lain Mankachu di Bengali dan Giant Taro atau Elephant Ear Taro di Inggris [5]. Tanaman ini telah lama digunakan sebagai obat tradisional di India untuk pengobatan pada perut atau limpa [6]. Selain itu, A. Macrorrhizos di Sanrangeng-Kabupatan Bone dan di Langgiri-Kabupaten Luwu Timur, Sulawesi Selatan digunakan untuk mengobati penyakit "raukeng" atau sakit pada bagian tubuh tertentu, Seperti perut, pinggang, punggung dan kepala. Penyakit ini juga ditandai dengan sakit ngilu yang berlebihan. Pengobatan tradisional untuk penyakit ini dengan menggunakan hasil parutan daun dan batang A. Macrorrhizos, serta biasanya dicampurkan dengan abu kayu bakar. Hasil parutan tersebut dapat pula menyembuhkan penyakit perut akut [7]. Sejauh ini, tanaman tersebut masih banyak digunakan di Sulawesi sebagai obat tradisional, namun penelitian terkait $A$. machrorrhiza belum pernah dilaporkan dari Indonesia. Artikel review ini bertujuan untuk mengintegrasikan fakta atau bukti ilmiah, terkait konstituen kimia atau senyawa metabolit sekunder dari $A$. machrorrhiza yang telah diisolasi dari beragam bagian tanaman dan aspek farmakologis yang telah dilaporkan.

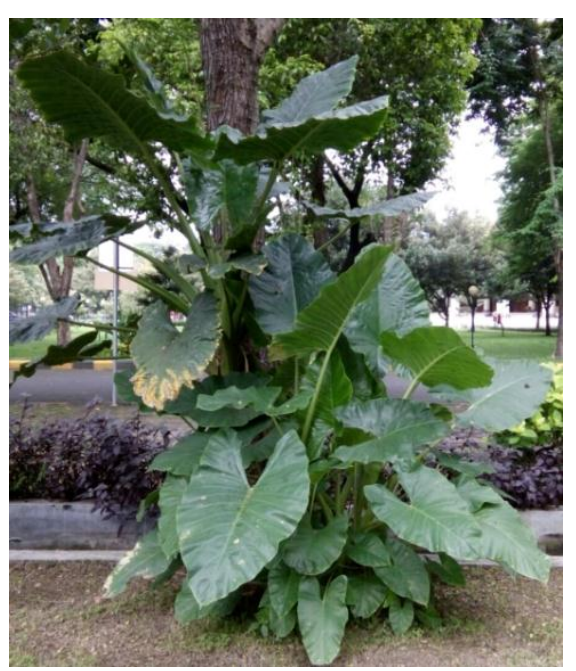

Gambar 1. Alocasia Machrorrhizos

Beberapa penelitian telah menunjukkan kandungan senyawa metabolit sekunder yang terdapat pada $A$. Macrorrhizos, antara lain flavonoid, glikosida sianogenetik, asam sitrat, asam askorbat dan polifenol [8]. Selain itu, tanaman tersebut juga memiliki protein, abu, serat kasar, karbohidrat, pati, oksalat, protease, nitrat dan tanin [9]. Flavonoid yang terkandung pada umbi $A$. macrorrhizos dilaporkan memiliki efek biologis sebagai antioksidan, antibakteri dan antidiare [10]. Ekstrak tanaman $A$. 
macrorrhizos juga memiliki aktivitas

biologis seperti antiinflamasi, antimikroba, antidiuretik, antidiabetes, antihipergikemik dan lain-lain (11].

\section{Taksonomi dan Botani.}

A. macrorrhizos berasal dari kingdom: plantae, divisi: magnoliophyta, class: liliopsida, family: araceae dan genus: alocasia [11]. A. macrorrhizos mudah tumbuh di area yang lembab dan tanah yang mengandung humus [12]. Bentuk daun melebar dengan ukuran $120 \mathrm{x}$ $50 \mathrm{~cm}$ berwarna hijau menyala. Batang memanjang hingga $1,3 \mathrm{~m}$. Bunga betina berbentuk kerucut silinder, ovarium berwarna hijau pucat, panjang $1-2 \mathrm{~cm}$ dengan diameter $1,5 \mathrm{~cm}$ sedangkan bunga jantan berbentuk silindris, panjang 3-7 cm dengan diameter $2 \mathrm{~cm}$ berwarna keputihan [1].

\section{Senyawa Metabolit Sekunder}

\subsection{Akar}

Isolasi senyawa telah dilakukan pada bagian akar tanaman A. macrorrhizos di Provinsi Hoabinh, Vietnam. Ekstraksi dilakukan pada serbuk akar tanaman tersebut dengan pelarut etanol. Ekstrak dipartisi dengan pelarut $n$-heksana, kloroform, etil asetat dan $n$-butanol. Fraksi etil asetat diperoleh dua senyawa dan dilanjutkan dengan karakterisasi strukturnya sehingga diperoleh senyawa (2S,3S,4R)-2N-[(2'R)-2'-hidroksiheksakosanoil]-tetradekana-1,3,4-triol dan (2S,3S,4R)-2N-[(2'R)-2'-hidroksiheksakosanoil]-heksadekana-1,3,4-triol [13]; [14].

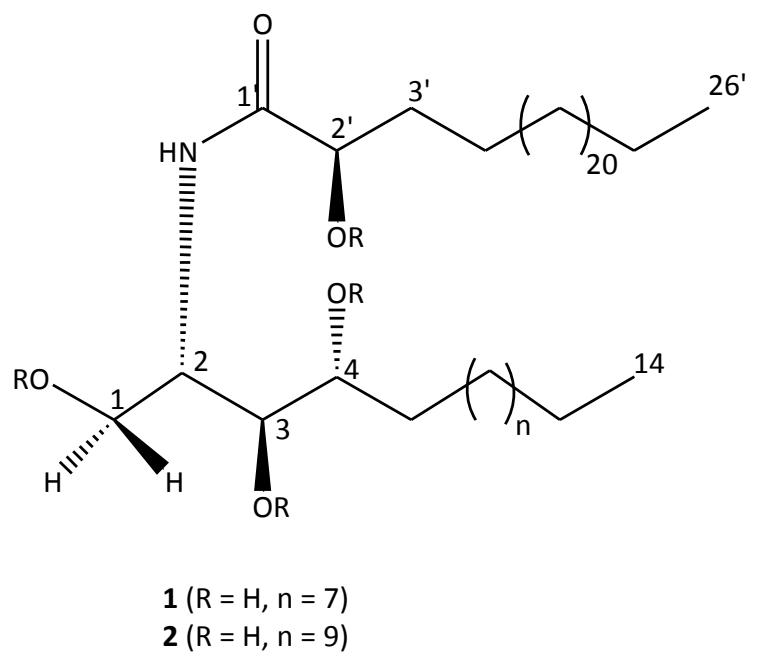




\subsection{Rimpang (Rhizome)}

Isolasi senyawa telah dilakukan pada bagian rimpang tanaman $A$. macrorrhizos di area kampus Jinan University, bukit Fenghuang dan di gunung Huolu daerah Provinsi Guangzhou, Cina. Ekstraksi dilakukan pada serbuk rimpang tanaman dengan pelarut etanol menggunakan metode maserasi. Ekstrak etanol yang diperoleh diekstraksi kembali dengan pelarut petroleum eter dan etil asetat. Ekstrak etil asetat yang diperoleh kemudian dielusi dengan $\mathrm{MeOH}: \mathrm{H}_{2} \mathrm{O}$ menggunakan kromatografi poliamida untuk memperoleh fraksi alkaloid. Fraksi tersebut menghasilkan 7 senyawa diantaranya hyrtiosin B (3), hyrtiosulawesin (4) dan 5 alkaloid indol (alokasin A-E) (5-9), [15]. Selain itu, ekstrak EtOH- $\mathrm{H}_{2} \mathrm{O}$ A. Machrorrhizos yang diperoleh melalui metode refluks, diekstraksi kembali dengan $\mathrm{CHCl}_{3}$, EtOAc dan $n$-Butanol. Fraksi $\mathrm{CHCl}_{3}$ dipisahkan lebih lanjut menggunakan kromatografi kolom silika gel dan diperoleh 12 subfraksi. Pemurnian menggunakan HPLC semipreparatif dan dilakukan karakterisasi sehingga diperoleh 6 senyawa dengan struktur (2S， 3R,6R)-2-metil-3-hidroksi piperidin. Senyawa tersebut adalah (2S,3R,6R)-2-metil-6-(1-fenilnonan-4-on9-il)piperidin-3-ol $\quad(\mathbf{1 0}), \quad(2 \mathrm{~S}, 3 \mathrm{R}, 6 \mathrm{R})-2-$ metil-6-(1-fenilnonan-5-on-9-il)piperidin3-ol (11), (2S,3R,6R)-2-metil-6-(9- fenilnonil)piperidin-3-ol (12), (2S,3S,6S)2-metil-6-(9-fenilnonil)-piperidin-3-ol

(13), (2R,3R,4S,6S)-2-metil-6-(9fenilnonil)piperidin-3,4-diol (14) dan (2R,3R,4R,6R)-2-metil-6-(9-fenilnonil)piperidin-3,4-diol (15) [16].

Pada penggunaan metode yang sama, dari fraksi kloroform diperoleh 14 senyawa diantaranya 5 senyawa lignanamida baru yaitu ( \pm )-(E)-3-(2-(3hidroksi-5-metoksifenil)-3-(hidroksimetil)7-metoksi-2,3-dihidrobenzofuran-5-il)-N(4-hidroksifenil)akrilamida (16), ( \pm )-(E)-3(2-(4-hidroksi-3,- $\quad$ 5-dimetoksifenil)-3(hidroksimetil)-7-metoksi-2,3dihidrobenzofuran-5-il)-N-(4hidroksifenil)akril- amida (17), ( \pm )-(Z)-3(2-(3-hidroksi-5-metoksifenil)-3(hidroksimetil)-7-metoksi-2,3-dihidrobenzofuran-5-il)-N-(4-hidroksifenil)akrilamida (18), ( $\quad$ ( )-(Z)-3-(2-(4-hidroksi-3,5dimetoksifenil)-3-(hidroksimetil)-7metoksi-2,3-dihidrobenzofuran-5-il)-N-(4hidroksifenil)akril-amida (19), ( $\quad$ ( )-4(Etoksi-(4-hidroksi-3-metoksifenil)metil)2-(4-hidroksi-3-metoksifenil)-N-(4hidroksifenil)tetrahidrofuran-3 karboksamida (20), monoindol alkaloid baru yaitu 1-(2-(5-Hidroksi-1H-indol-3-il)2-oksoetil-1H-pirol-3-karbaldehid (21) dan 8 senyawa yang telah ditemukan sebelumnya yaitu grossamida (22), cisgrossamida (23), 5-hidroksi-1H-indol-3glioksilat metil ester (24), 5-hidroksi-1H- 
indol-3-glioksi etil ester (25), 1H-indol-3-

karbaldehid (26), 1H-indol-3-asam karboksilat (27), 5-hidroksi-1H-indol-3- karbaldehid (28) dan 5-hidroksi-1H-indol-

3-asam karboksilat etil ester (29) [17].<smiles>O=C(C(=O)c1c[nH]c2ccc(O)cc12)C1=CNC2C=CC(O)=CC12</smiles>

3<smiles>Oc1ccc2[nH]cc(-c3cnc(-c4c[nH]c5ccc(O)cc45)cn3)c2c1</smiles>

5<smiles>COc1cc(/C=C/C(=O)NCC(=O)C2CNc3ccc(O)cc32)ccc1O</smiles>

9<smiles>O=C(c1c[nH]c2ccc(O)cc12)c1cccc2c1[nH]c1ccc(O)cc12</smiles><smiles>[R]c1cc(/C=C/C(=O)NC([R])C(=O)C2CNc3ccc(O)cc32)cc(OC)c1O</smiles>

$6\left(\mathrm{R}=\mathrm{H}, \mathrm{R}^{\prime}=\mathrm{H}\right)$

$7\left(\mathrm{R}=\mathrm{H}, \mathrm{R}^{\prime}=\mathrm{OCH}_{3}\right)$

$8\left(\mathrm{R}=\mathrm{OCH}_{3}, \mathrm{R}^{\prime}=\mathrm{H}\right)$<smiles>CC(CCc1ccccc1)C(=O)CC=CCC[C@H]1CSC(O)[C@H](C)N1</smiles>

10<smiles>C[C@H]1N[C@H](CCCCCCCCCc2ccccc2)CC[C@H]1O</smiles>

12<smiles>C[C@H]1N[C@H](CCCCCCCCCc2ccccc2)C[C@@H](O)[C@@H]1O</smiles><smiles>C[C@H]1N[C@H](CCCCC(=O)CCCCc2ccccc2)CC[C@@H]1O</smiles>

11<smiles>C[C@H]1N[C@@H](CCCCCCCCCc2ccccc2)CC[C@@H]1O</smiles>

13<smiles>CC1N[C@H](CCCCCCCCCc2ccccc2)C[C@H](O)C1O</smiles> 

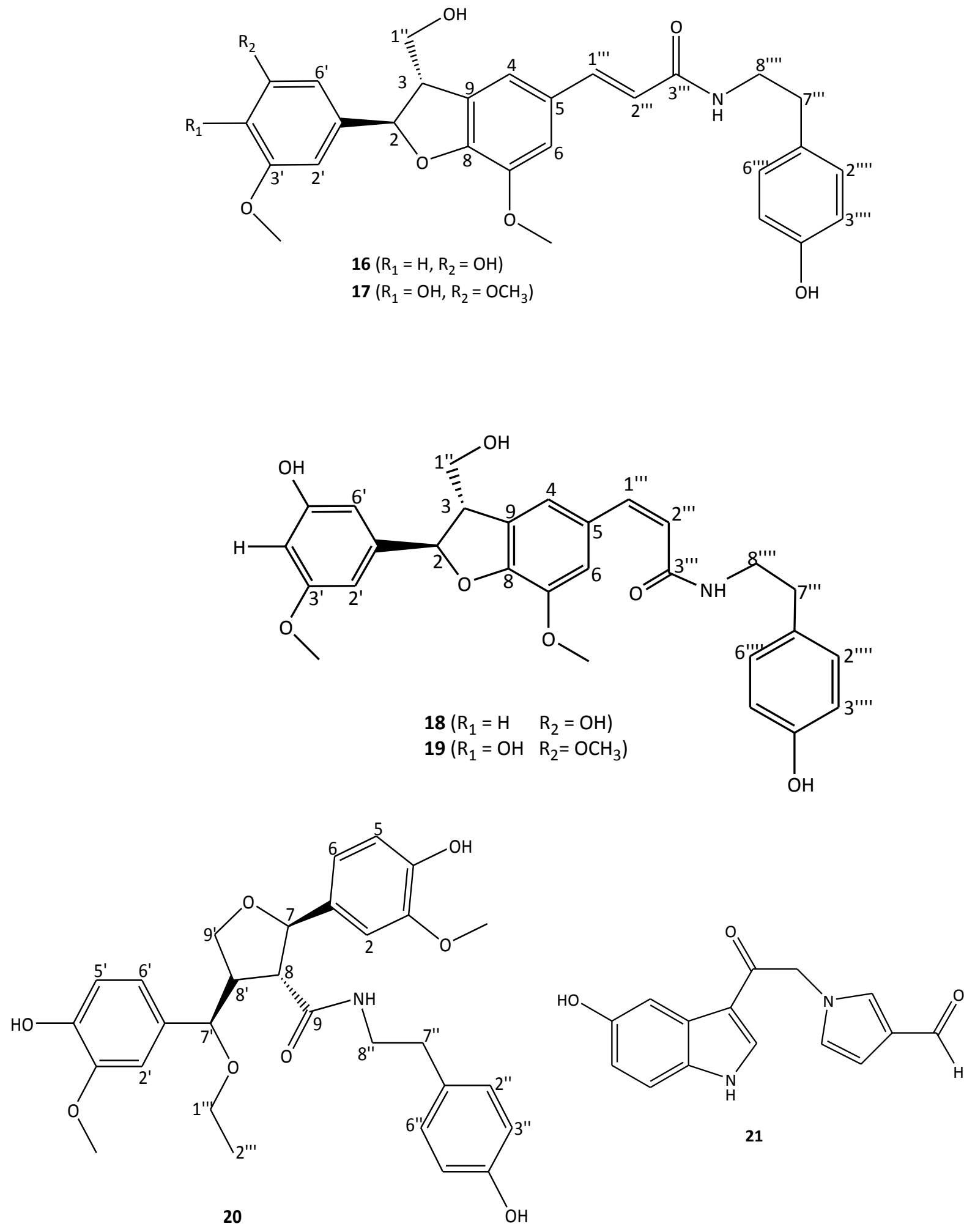

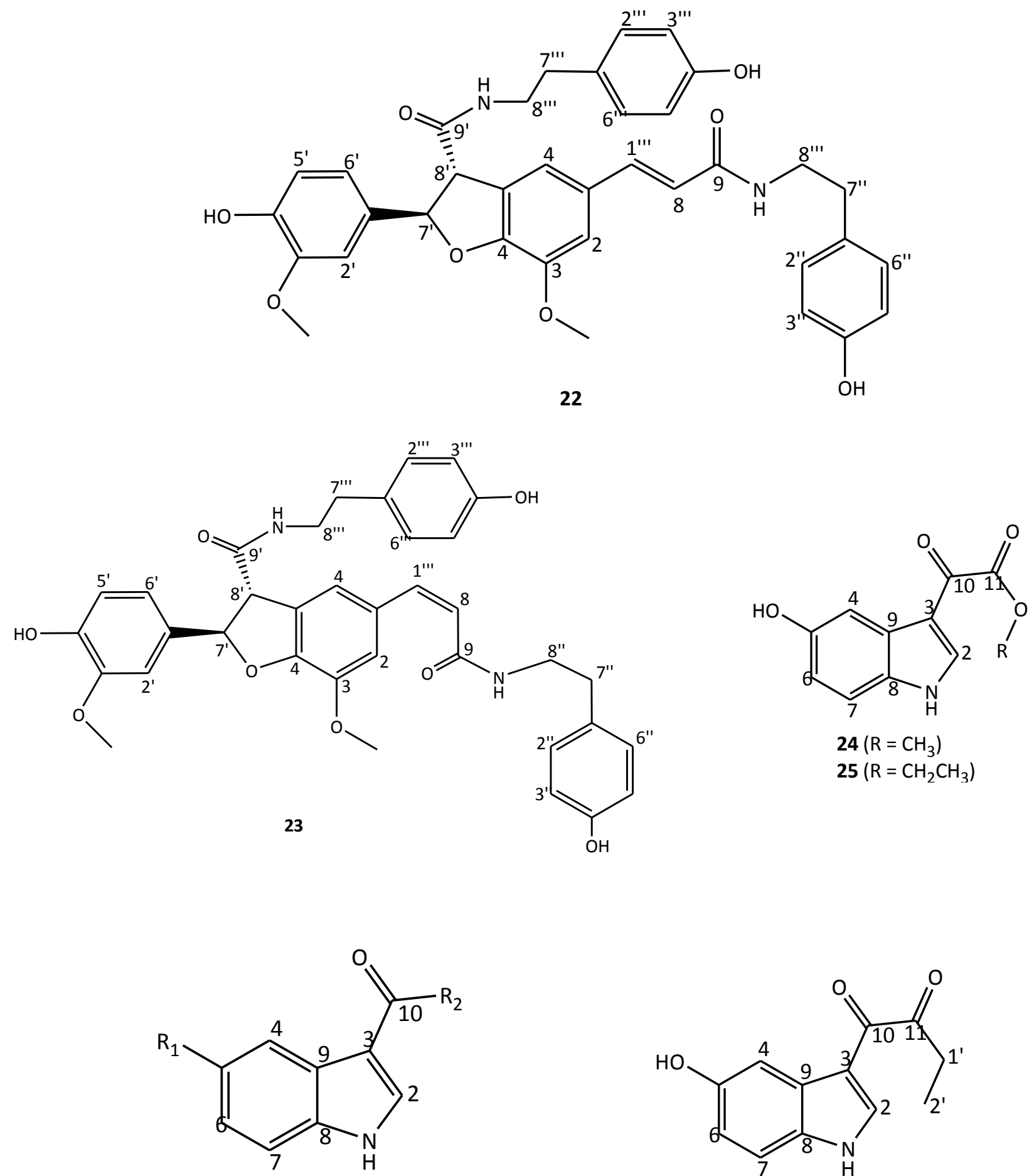

$26(\mathrm{R} 1=\mathrm{H}, \mathrm{R} 2=\mathrm{H})$

$27(\mathrm{R} 1=\mathrm{H}, \mathrm{R} 2=\mathrm{OH})$<smiles>CCC(=O)C(=O)c1c[nH]c2ccc(O)cc12</smiles>

$28(\mathrm{R} 1=\mathrm{OH}, \mathrm{R} 2=\mathrm{H})$

29 


\subsection{Daun}

Isolasi senyawa juga telah dilakukan pada bagian daun tanaman A. macrorrhizos. Isolasi menggunakan metode hidrolisis dengan penambahan glikosida yang dilelehkan dengan $\mathrm{H}_{2} \mathrm{O}$ dan $\mathrm{AcOH}$ dalam botol pada suhu $100^{\circ} \mathrm{C}$ dan $\beta$-glukosidase pada suhu $40^{\circ} \mathrm{C}$. Glukosa diidentifikasi menggunakan PC (Paper Chromatography) dan GLC (Gas Liquid Chromatography). Analisis dari spektrum $I R$ (Infra-Red) dan<smiles>N#C/C(OC1OC(CO)C(O)C(O)C1O)=C(\C=C/C(=O)O)CC(=O)O</smiles>

30 spektrum NMR (Nuclear magnetic resonance) dengan TMS (tetrametilsilan) glikosida menunjukkan bahwa senyawa yang diidentifikasi merupakan senyawa yang identik dengan triglochinin. Sehingga diperoleh senyawa triglochinin dengan struktur O-[ $\beta$-D-glukopiranosil]-1-siano-1hidroksi-2-metilkarboksi-4- $\alpha-1,2(\mathrm{E})-\alpha-3,4(\mathrm{Z})$ butadiena (30) dan isotriglochinin O- $[\beta-D-$ glukopiranosil]-1-siano-1-hidroksi-2metilkarboksi-4-karboksi- $\alpha-1,2(\mathrm{E})-\alpha$ 3,4(E)butadiena (31)[18];[19];[20].<smiles>N#C/C(OC1OC(CO)C(O)C(O)C1O)=C(\C=C\C=O)CC=O</smiles>

31

dapat dilakukan secara in vivo pada tikus albino dengan menggunakan metode tes lipschitz et. al. (1943). Jenis tikus albino yang digunakan yaitu tikus yang memiliki berat sekitar 150 sampai 200 mg. Tikus dibagi dalam lima kelompok. Kelompok pertama diberikan garam secara normal, kelompok kedua diberikan furesemid, kelompok ketiga, keempat dan kelima diberikan masing-masing 
ekstrak etanol A. macrorrhizos [24]. Urinnya diukur setiap 5 jam. Urin yang dihasilkan diperkirakan mengandung elektrolit $\left(\mathrm{Na}^{+}, \mathrm{K}^{+}\right.$dan $\left.\mathrm{Cl}^{-}\right)$yang memiliki aktivitas diuretik. $\mathrm{Na}^{+}$dan $\mathrm{K}^{+}$ diuji pada fotometri nyala api sedangkan $\mathrm{Cl}^{-}$diuji dari titrasi menggunakan $0,02 \mathrm{~N}$ perak nitrat $\left(\mathrm{AgNO}_{3}\right)$ dengan 5\% kalium kromat $\left(\mathrm{K}_{2} \mathrm{CrO}_{4}\right)$ sebagai indikator [25]. Ekstrak etanol A. macrorrhizos secara signifikan meningkatkan urin yang keluar pada konsentrasi dosis yang paling tinggi (400 mg/kg). Hal ini menunjukkan bahwa ekstrak etanol A. macrorrhizos meningkatkan eskresi ion $\mathrm{Na}^{+}, \mathrm{K}^{+}$dan $\mathrm{Cl}^{-}$ pada dosis yang tinggi. Hasil tersebut lebih rendah daripada standar obat furosemid (20mg/kg) [24] dan sudah baik sebagai antidiuretik dari bahan alam.

\subsection{Aktivitas Antikanker}

Antikanker merupakan obat dengan kandungan senyawa yang dapat mencegah dan mengobati jaringan sel dalam tubuh [26]. Pengujian antikanker dapat dilakukan secara in vitro menggunakan metode MTT (3-[4,5dimethylthiazol-2-yl]-2,5-

dipheniltetrazolium bromide) [27];[28] dengan menentukan aktivitas mitokondria [29]. Ekstrak air A. macrorrhizos memberikan efek sedang pada konsentrasi $\left(\mathrm{IC}_{50}\right)$ yaitu $414 \mu \mathrm{g} / \mathrm{mL}$ untuk sel kanker dan $1462 \mu \mathrm{g} / \mathrm{mL}$ untuk sel hati normal [30]. Ekstrak etil asetat $A$. macrorrhizos juga memberikan efek yang signifikan terhadap sel tumor A549, B16, BGC-823 yang juga dilakukan dengan metode $M T T$ [31]. Hasil $\mathrm{IC}_{50}$ dari ekstrak etil asetat A. macrorrhiza pada sel tumor A549, B16 dan BGC-823 masing-masing adalah 94,6; 541,9 dan $629,5 \mu \mathrm{g} / \mathrm{mL}$ [30]. Selain itu, beberapa senyawa piperidin yang telah diisolasi dari ekstrak etanol A. macrorrhizos seperti 10-15 memiliki aktivitas sitotoksik terhadap empat jenis sel kanker manusia (CNE-1, Detroit 562, Fadu, MGC-803 dan MCF-7) dengan $\mathrm{IC}_{50}$ kurang dari $10 \mu \mathrm{g} / \mathrm{mL}$ [16].

\subsection{Aktivitas antioksidan}

Antioksidan merupakan molekul yang dapat menstabilkan radikal bebas atau menghentikan reaksi radikal bebas dalam tubuh makhluk hidup, dengan cara memberikan elektronnya [32];[33];[34]. Antioksidan dapat dilakukan secara kuantitatif menggunakan metode DPPH (1,1-difenil-2-pikrilhidrazil) [35],[36]. Ekstrak metanol rimpang $A$. macrorrhizos dengan menggunakan metode DPPH memiliki aktivitas maksimal dengan $\mathrm{IC}_{50} 693 \mu \mathrm{g} / \mathrm{mL}$ sedangkan $\mathrm{IC}_{50}$ dari kontrol positif asam askorbat adalah 48,38 $\mu \mathrm{g} / \mathrm{mL}$ [5]. Hal ini menunjukkan bahwa aktivitas antioksidan ekstrak metanol rimpang $A$. macrorrhizos lebih rendah dibandingkan dengan asam askorbat. Sementara itu, ekstrak etanol memiliki aktivitas 
antioksidan yang lebih baik dengan $\mathrm{IC}_{50}$ 2,$5 ; 1,2 ; 1,13$ dan $1,42 \mu \mathrm{g} / \mathrm{mL}[6]$ dan ekstrak dietil eter akar dan rimpang $A$. macrorrhizos juga memiliki efek biologis antioksidan yang signifikan dengan $\mathrm{IC}_{50}$ masing-masing $34,51 \mathrm{dan} 48,01 \mu \mathrm{g} / \mathrm{mL}$, sedangkan asam askorbat dan kuercetin sebagai kontrol positif diperoleh $\mathrm{IC}_{50}$ 78,17 dan $53,60 \mu \mathrm{g} / \mathrm{mL}[37]$.

\subsection{Aktivitas Antimikroba}

Antimikroba berfungsi melawan pertumbuhan baik pada bakteri, jamur maupun mikroba jenis lainnya [38] yang kebanyakan diperoleh dari tanaman [39];[40]. Pengujian antimikroba dapat dilakukan secara in vitro dengan metode difusi agar [41]. Beberapa ekstrak daun A. macrorrhizos memiliki efek biologis antimikroba dengan menggunakan metode tersebut. Seperti ekstrak air $A$. macrorrhizos memberikan hambatan maksimum 14,4 $\mathrm{mm}$ terhadap Staphylococcus aureus, ekstrak petroleum eter memberikan hambatan maksimum $\quad 15,15 \quad \mathrm{~mm}$ terhadap Asperigillus niger. Ekstrak kloroform memberikan hambatan maksimum 17,14 mm terhadap S. aureus. Ekstrak aseton memberikan hambatan maksimum 17,21 $\mathrm{mm}$ terhadap Bacillus subtilis dan ekstrak etanol memberikan hambatan maksimum 22,15 mm terhadap B.subtilis. Namun, penghambatan yang diperoleh tersebut masih berada dibawah aktivitas kontrol positif gentamisin dan flukonazol dan nilai MIC (Minimum Inhibitory Concentration) terbaik adalah pada ekstrak etanol terhadap bakteri B. subtilis yaitu $10,23 \mathrm{mg} / \mathrm{mL}$ [42].

\subsection{Aktivitas antidiabetes}

Antidiabetes merupakan obat yang dapat mengontrol tingkat glukosa darah pada penderita diabetes [43];[44]. Ekstrak etanol daun dan batang $A$. macrorrhizos memiliki efek biologis antidiabetes yang dilakukan secara in vivo dengan menggunakan hewan uji tikus (Rattus norvegicus). Darah tikus dikumpulkan pada ekornya (dengan memotong tepi ekor) pada hari ke-1, ke7, ke-14 dan ke-21. Analisis menggunakan ANOVA dengan uji $t$ dan perbedaan signifikan $(\mathrm{P}<0,05)$. Hasil menunjukkan efek signifikan pada waktu 21 hari yaitu 136,84 dan 109,63 mg/dL pada dosis 200 dan $400 \mathrm{mg} / \mathrm{kg}$ dari ekstrak daun etanol A. macrorrhizos dan ekstrak etanol batang tanaman tersebut adalah 138,31 dan 111,26 mg/dL pada dosis 200 dan $400 \quad \mathrm{mg} / \mathrm{kg}$ [45]. Sedangkan glibenklamida sebagai kontrol positif menunjukkan tingkat glukosa dalam tubuh sebesar 96,23 mg/dL pada $10 \mathrm{mg} / \mathrm{kg}$ [44]. Ekstrak petroleum eter menunjukkan peningkatan yang signifikan pada berat badan, penurunan kadar glukosa darah [46];[47] dan profil 
lipid serum (kolesterol \& trigliserida) [47].

\subsection{Aktivitas Antihiperglikemik}

Antihiperglikemik adalah suatu zat yang berfungsi untuk menurunkan kadar gula dalam darah [48];[49]. Ekstrak metanol rimpang A. macrorrhizos memiliki efek biologis antihiperglikemik dengan melakukan pengujian sevara in vivo terhadap tikus albino. Analisis menggunakan ANOVA dengan uji $t$ dan perbedaan signifikan $\quad(\mathrm{P}<0,01)$ Pemberian dosis $500 \mathrm{mg} / \mathrm{kg}$ berhasil menurunkan kadar glukosa darah $(55,49 \%)$ selama 8 jam pengobatan. Hasil tersebut lebih baik dari pada kontrol obat metformin [5].

\subsection{Aktivitas Antiinflamasi}

Antiinflamasi disebut juga sebagai obat nonsteroid yang dapat digunakan untuk menyembuhkan penyakit radang yang ditimbulkan oleh bagian tubuh yang mengalami cedera [50]. Ekstrak etanol rimpang A. macrorrhizos menunjukkan aktivitas antiinflamasi yang dapat dilakukan secara in vivo terhadap tikus albino. Hasil menunjukkan efek hambat ekstrak etanol rimpang A. macrorrhizos signifikan mulai dari jam pertama sampai jam kelima dan efek penghambatan maksimum diperoleh saat pemberian dosis 300 dan $600 \mathrm{mg} / \mathrm{kg}$ dengan penghambatan 25,43\% (P<0,001) dan $41,05 \%$ pada jam ketiga. Sedangkan aspirin memiliki penghambatan sebesar $51,38 \%(\mathrm{p}<0,001)$ dengan dosis 150 $\mathrm{mg} / \mathrm{kg}$ [51]. Beberapa senyawa yang telah diisolasi dari ekstrak etanol $A$. macrorrhizos juga memiliki aktivitas antiinflamasi yang dilakukan secara in vitro dengan mengamati efek hambatan terhadap nitrat oksida yang diinduksi oleh lipopolisakarida (LPS) dalam sel RAW 264,7, aktivitas antiproliferatif terhadap epitel karsinoma nasofaring manusia (CNE-1), karsinoma lambung manusia (MGC-803) dan sel kanker payudara manusia (MCF-7). Hasil menunjukkan bahwa senyawa 17, 19, 22 dan $\mathbf{2 3}$ memiliki aktivitas yang signifikan pada penghambatan produksi nitrat oksida dengan $\mathrm{IC}_{50}$ masing-masing $2,35 \pm 0,38, \quad 9,20 \pm 0,94, \quad 3,45 \pm 0,39$ dan $7,96 \pm 0,56 \mu \mathrm{M}$ [17]. Selain itu, ekstrak etanol daun A. macrorrhizos juga dilaporkan aktif sebagai antiinflamasi karena mengandung flavonoid [52].

\subsection{Aktivitas Antelmintik}

Antelmintik atau sering juga disebut sebagai obat cacing merupakan obat yang dapat membunuh cacing dalam usus atau jaringan tubuh makhluk hidup [53];[54] baik berupa cacing pita maupun cacing bulat [55]. Akar kering A. macrorrhizos memiliki aktivitas 
antelmentik yang dilakukan dengan cara in vivo menggunakan pengujian terhadap cacing tanah (Pheretima posthuma) karena baik anatomis maupun fsikologisnya memiliki kemiripan dengan cacing gelang pada tubuh manusia. Aktivitas antelmintik dilakukan sesuai metode yang dijelaskan oleh Mali et al. dengan sedikit modifikasi. Ekstrak alkohol (100 $\mathrm{mg} / \mathrm{mL})$ menunjukkan waktu kelumpuhan dan waktu kematian masing-masing 41.10 dan 43.51 menit, sedangkan pada fraksi etil asetat (100 $\mathrm{mg} / \mathrm{mL}$ ) masing masing 5,33 dan 8,15 menit dan standar albendazol $(100$ $\mathrm{mg} / \mathrm{mL}$ ) menunjukkan waktu kelumpuhan dan waktu kematian masingmasing 1,10 dan 1,43 menit [56].

Selain itu, Ekstrak hidroalkoholik daun A. indica menunjukkan aktivitas antelmintik dengan waktu kelumpuhan dan kematian masing-masing 4,27 menit dan 10,58 menit $(10 \mathrm{mg} / \mathrm{mL})$, fraksi etil asetat dan petroleum eter menyebabkan kelumpuhan masing-masing 6,28 dan 5,63 menit dan waktu kematian masingmasing 21.59 dan 11.92 menit. Sedangkan standar obat piperazin sitrat (10 $\mathrm{mg} / \mathrm{mL})$ menyebabkan kelumpuhan dan kematian masing-masing 19.26 dan 63.25 menit. Hal ini menunjukkan bahwa ekstrak hidroalkoholik daun A. indica memiliki kemampuan yang lebih besar untuk membunuh cacing tanah daripada piperazin yang merupakan obat standar [57].

\subsection{Aktivitas Antidiare}

Antidiare merupakan obat yang digunakan untuk menyembuhkan penyakit diare yang disebabkan oleh bakteri dan mikroba [58];[59]. Ekstrak etanol daun A. macrorrhizos secara in vitro diujikan terhadap bakteri E. coli, Salmonella typhimurium dan Shigella menggunakan metode difusi agar. Konsentrasi mikroba $1 \times 10^{8} \mathrm{CFU} / \mathrm{mL}$ digunakan untuk aktivitas antidiare. Ekstrak air dan etanol A. macrorrhizos menunjukkan aktivitas antidiare dan lebih kuat dibandingkan dengan obat standar ciprofloxacin $(10 \mu \mathrm{g} / \mathrm{mL})$. Ekstrak tanaman ini juga memiliki efek biologis yang besar terhadap protozoa dibandingkan dengan obat amebicidal dan giardicidal [60].

\section{Kesimpulan}

Tanaman A. macrorrhizos merupakan tanaman yang digunakan sebagai obat tradisional di beberapa daerah di Indonesia. Senyawa metabolit sekunder dari tanaman ini telah diisolasi dari akar, rimpang dan daunnya. Beberapa aktivitas biologis yang dilaporkan telah memperkuat fakta-fakta ilmiah bahwa tanaman ini memiliki aspek farmakologi yang baik. Penelitian lebih lanjut terkait keamanan dan penggunaan 
dosis yang tepat perlu dilakukan. Selain itu, penelitian mengenai isolasi senyawa metabolit sekunder lain, masih perlu dilanjutkan guna mengetahui senyawasenyawa yang berpotensi memiliki fungsi dalam aspek farmakologi.

\section{Daftar Pustaka}

[1] P. C. Boyce, "A review of Alocasia (Araceae: Colocasieae) for Thailand including a novel species and new species records from South-west Thailand," Thai Forest Bulletin (Botany), vol. 36, pp. 1-17, 2008.

[2] M. Rahmatullah, A. K. Das, A. H. Mollik, R. Jahan, M. Khan, T. Rahman, and M. H. Chowdhury, “An ethnomedicinal survey of dhamrai sub-district in Dhaka District, Bangladesh," American-Eurasian Journal of Sustainable Agriculture, vol. 3, pp. 881-888, 2009.

[3] A. Hay and R Wise, "The genus Alocasia (Araceae) in Australia," Blumea, vol. 35, pp. 499-545, 1991.

[4] S. Chotimah and D. T. Fajarini, "Reduksi kalsium oksalat dengan perebusan menggunakan larutan $\mathrm{NaCl}$ dan penepungan untuk meningkatkan kualitas sente (Alocasia macrorrhiza) sebagai bahan pangan," Jurnal Teknologi Kimia dan Industri, vol. 2, pp. 76-83, 2013.

[5] M. Rahman, A. Hossain, S. A. Siddique, K. P. Biplab, and M. H.
Uddin, "Antihyperglycemic, antioxidant, and cytotoxic activities of Alocasia macrorrhizos (L.) rhizome extract," Turkey Journal Biology, vol. 36, pp. 574-579, 2012.

[6] S. Pal, A. Bhattacharjee, S. Mukherjee, K. Bhattacharya, and S. Khowala, "Antioxidant and hepatoprotective activity of ethanolic extract of Alocasia indica tuber," American Journal of Phytomedicine and Clinical Therapeutics, vol. 2, pp. 191-208, 2014.

[7] D. M. Kaaiakamanu and J. K. Akina, "Hawaiian herbs of medicinal value," Hawaii: University Press of the Pasific Honolulu, 2003.

[8] W. A. Mulla, V. R. Salunke, and S. B. Bhise, "Hepatoprotective activity of hydroalcoholic extract of leaves of Alocasia indica (Linn.)," Indian Journal of Experimental Biology, vol. 47, pp. 816-821, 2009.

[9] S. K. Singh, J. R. Patel, A. Dangi, D. Bachle, and R. K. Katariya, "A review paper on Alocasia macrorrhiza tradional Indian medicinal plant," European Journal of Pharmaceutical and Medical Research, vol. 4, pp. 366-375, 2017.

[10] K. Islam, I. Mahmud, S. Saha, A. B. Sarker, H. Mondal, A. S. M. MonjourAl-Hossain, and Anisuzzman, "Preliminary pharmacological evaluation of Alocasia indica Schott 
tuber," Journal of Intergrative Medicine, vol. 11, pp. 343-351, 2013.

[11] V. Srivastava, S. Mubeen, B. C. Semwal, and V. Misra,"Biological activities of Alocasia macrorrhiza: A review," Journal of Science, vol. 2, pp. 22-29, 2012.

[12] T. K. Lim, "Alocasia macrorrhizos, "Edible Medicinal and Non Medicinal Plants, vol. 9, pp. 429-442, 2015.

[13] N. Q. Tien, P. H. Ngoc, P. H. Minh, P. V. Kiem, C. V. Minn, and Y. H. Kim, "New ceramide from Alocasia macrorrhiza," Archives of Pharmacal Research, vol. 27, pp. 1020-1022, 2004.

[14] N. Q. Tien, P. H. Ngoc, P. H. Minh, P. V. Kiem, and Y. H. Kim, "Two new aloceramides from Alocasia machrorrhiza," Journal of Chemistry, vol. 43, pp. 513-516, 2005.

[15] L. Zhu, C. Chen, H. Wang, W. Ye, and G. Zhou, "Indole alkaloids from Alocasia machrorrhiza," Chemical and Pharmaceutical Bulletin, vol. 60, pp. 670-673, 2012, 2012.

[16] W. Huang, X. Yi, J. Feng, Y. Wang, and X. He, "Piperidine alkaloids from Alocasia macrorrhiza," Phytochemistry, vol. 143, pp. 81-86, 2017.

[17] W. Huang, C. Li, Y. Wang, X. Yi, and X. He, "Anti-inflammatory lignanamides and monoindoles from
Alocasia machrorrhiza," Fitoterapia, vol. 117, pp. 126-132, 2017.

[18] A. Nahrstedt, "Cyanogenese der araceen," Phytochemistry, vol. 14, pp. 1339-1340, 1974.

[19] W. Hosel and O. Klewitz, "Betaglucosidases specific for the cyanogenic glucoside triglochinin from Alocasia macrorrhiza Schott: further characterization of properties," Hoppe Seyler's Zeitschrift fur Physiologische Chemie, vol. 358, pp. 959-966, 1977.

[20] W. Hosel and A. Nahrstedt, "Glucosidases specific for the cyanogenic glucoside triglochinin. Purification and characterization of beta-glucosidases from Alocasia macrorrhiza Schott," Hoppe Seyler's Zeitschrift fur Physiologische Chemie, vol. 356, pp. 1265-1275, 1975.

[21] M. E. Ernst, Pharm. D., and Marvin Moser, M.D., "Use of diuretics in patients with hypertension," Journal of Medicine, vol. 361, pp. 2153-2164, 2009.

[22] F. C. Bart'ter and W. B. Schwartz, "The syndrome of inappropriate secretion of antidiuretic hormone," American Journal of Medicine, vol. 42, pp. 790-806, 1967.

[23] E. B. Verney, "The antidiuretic hormone and the factors which determine its release,"Proceedings of 
the Royal Society of London. Series

B, Biological Sciences , pp. 25-206, 1947.

[24] U. S. Mubeen, M.Vimlesh, and B. Santanu, "Laxative and Diuretic Property of Ethanolic Extract of Leaves of Alocasia macrorrhiza Linn. on Experimental Albino Rats," International Research Journal of Pharmacy, vol. 3, pp. 174-176, 2012.

[25] S. R. Kane, V. A. Apte, S. C. Todkar, and S. K. Mohite, "Diuretic and laxative activity of ethanolic extract and its fractions of Euphorbia Thymifolia Linn," International Journal of ChemTech Research, vol. 1, pp. 149-152, 2009.

[26] V. Beljanski, L. G. Marzilli, and P. W. Doetsch, "DNA damageprocessing pathways involved in the eukaryotic cellular response to anticancer DNA cross-linking drugs," Molecular Pharmacology, vol. 65, pp. 1496-1506, 2005.

[27] Y. Liu, D. A. Peterson, H. Kimura, and D. Schubert, "Mechanism of cellular 3-(4,5-dimethylthiazol-2-yl)2,5-diphenyltetrazolium bromide (MTT) reduction," Journal of Neurochemistry, vol. 69, pp. 581-593, 1997.

[28] K. Abe and N. Matsuki, "Measurement of cellular 3-(4,5dimethylthiazol-2-yl)-2,5diphenyltetrazolium bromide (MTT) reduction activity and lactate dehydrogenase release using MTT," Neuroscience Research, vol. 38, pp. 325-329, 2000.

[29] J. van Meerloo, GJ. Kaspers, and J. Cloos, "Cell sensitivity assays: the MTT assay," Methods Molecular Biology, vol. 731, pp. 237-245, 2011.

[30] S. Fang, C. Lin, Q. Zhang, L. Wang, P. Lin, J. Zhang, and X. Wang "Anticancer otential of aqueous extract of Alocasia macrorrhiza against hepatic cancer in vitro and in vivo," Journal of Ethnopharmacology, vol. 141, pp. 947- 956, 2012.

[31] Z. Jun, "Anticancer effects of diffenent solvent extracts from Alocasia Macrorrhiza in vitro," Lishizhen Medicine and Materia Medica Research, 2008.

[32] M. L. Wahlquist "Antioxidant relevance to human health," Asia Pacific Journal of Clinical Nutrition Mini Review, vol. 22, pp. 171-176, 2013.

[33] P. Molyneux, "The use of the stable free radical diphenylpicrylhydrazyl (DPPH) for estimating antioxidant activity," Journal of Science Technology, vol. 26, pp. 211-219, 2004.

[34] V. Bondet, W. B. Williams, and C. Berset, "Kinetics and mechanisms of antioxidant activity using the DPPH free radical method" Lebensmittel- 
Wissenschaft and Technologie, vol. 30, pp. 609-615, 1997.

[35] Om. P. Sharma, and Tej K. Bhat, "DPPH antioxidant assay revisited," Journal of Food Chemistry, vol. 113, pp. 1202-1205, 2009.

[36] K. Mishra, Ojha, and N. K. Chaudhury, "Estimation of antiradical properties of antioxidants using DPPH Assay: A critical review and results," Food Chemistry, vol. 130, pp. 10361043, 2012.

[37] P. Mandal, T. K. Misra, and I. D. Singh, "Antioxidant activity in the extracts of two edible aroids," Indian Journal of Pharmaceutical Science, vol. 72, pp. 105-108, 2010.

[38] M. Zasioff, "Antimicrobial peptides of multicellular organisms," Nature, vol. 415, pp. 389-395, 2002

[39] J. L. Rios, and M. C. Recio, "Medicinal plants and antimicrobial activity," Journal of Ethnopharmacology, vol. 100, pp. 8084, 2005.

[40] M. M. Cowan, "Plant products as antimicrobial agents," Clinical Microbiology Reviews, vol. 12, pp. 564-582, 1999.

[41] M. R. S. Zaidan, A. N. Rain, A. R. Badrul, A. Adlin, A. Norazah, and I. Zakiah, "In vitro screening of five local medicinal plants for antibacterial activity using disc diffusion method,"
Tropical Biomedicine, vol. 22, pp. 165-170, 2005.

[42] W. A. Mulla, et al., "Evaluation of antimicrobial activity of leaves of Alocasia Indica Linn.," International Journal of PharmTech Research, vol. 2, pp. 327-333, 2010.

[43] A. Tokajuk, E. Krzyzanowska-Grycel, A. Tokajuk, S. Grycel, A. Sadowska, and H. Car, "Antidiabetic drugs and risk of cancer," Pharmacological Reports, vol. 67, pp. 1240-1250, 2015.

[44] N. Malviya, S. Jain, and S. Malviya, "Antidiabetic potential of medicinal plants," Acta Poloniae PharmaceuticDrug Research: Review, vol. 67, pp. 113-118, 2010.

[45] R. Karim, N. Ferdaus, N. Roy, S. C. D. Sharma, S. Jahan, and M. S Shovon, "A study on antidiabetic activity of the leaf and stem of Alocasia indica L. in steptozotocin induced diabetic rats," International Journal of Biosciences, vol. 5, pp. 195-202, 2014.

[46] T. Jawaid, S. Argal, and M. Kamal, "Antidiabetic and antihyperlipidemic effcets of the ethanolic extract of Alocasia indica rhizomes in high fat diet/streptozotocin and streptozotocin/nicotinamide-induced type 2 diabetic rats," Asian Journal of Pharmaceutical and Clinical Research, vol 8, pp. 58-62, 2015 
[47] S. H. Patil, S. A. Sreenivas, P. V. Deshmukh, M. Srikanth, A. Choudhury, and A. E. Wagh, "Antidiabetic and hypolipidemic potential of Alocasia indica Schott. leaves in streptozotocin induced diabetic rats," International Journal of Drug Development and Research, vol. 4, pp. 368-374, 2012.

[48] M. C. Bertoluci, D. Uebele, A. Schmidt, F. C. S. Thomazelli, F. R. Oliveira, and H. Schmid,"Urinary TGF- $\beta 1$ reduction related to a decrease of systolic blood pressure in patients with type 2 diabetes and clinical diabetic nephropathy," Diabetes Research and Clinical Practice, vol. 72, pp. 258-264, 2006.

[49] A. Y. Y. Cheng, and I. G. Fantus, "Oral antihyperglycemic therapy for type 2 diabetes militus," Review Synthese: Canadian Medical Association or its Licensor, vol. 172, pp. 213-226, 2005.

[50] N. Vergnolle, "The inflammatory response," Drug Development Research, vol. 59, pp. 375-381, 2003.

[51] A. Rahman, Solaiman, E. Haque, and A. K. Das, "Analgesic and antiinflammatory activities of Alocasia indica (Roxb.) Schott," Oriental Pharmacy and Experimental Medicine, vol. 11. Pp. 143-146, 2011.

[52] W. A. Mulla, S. B. Kuchekar, V. S. Thorat, A. R. Chopade, and B. S.
Kuchekar,

"Antioxidant, antinociceptive and anti-inflammatory activities of ethanolic extract of leaves of Alocasia indica (Schott.)," Journal of Young Pharmacists, vol. 2, pp. 138-143, 2010.

[53] P. Yadav, and R. Singh, "A review on anthelmintic drugs a nd their future scope," International Journal Of Pharmacy and Pharmaceutical Sciences, vol. 3, pp. 17-21, 2011.

[54] R. Kaminsky, P. Durcay, M. Jung, R. Clover, L. Rufener, J. Bouvier, S. S. Weber, A. Wenger, S. WielandBerghausen, T. Goebel, N. Gauvry, F. Pautrat, T. Skripsky, O. Froelich, C. Komoin-Oka, B. Westlund, A. Sluder, and P. Maser, "A New class of anthelmintics effective against drugresistant nematodes," Nature, vol. 452, pp. 176-181, 2008.

[55] L. H. Dye and R. J. Walker, "Anthelmentic drug,". The C. elegans Research Community, 1-12, 2007.

[56] S. H. Patil, S. A. Sreenivas, P. V. Deshmukh, Srikanth, A. Choudhury, A. E. Wagh, and L. S. Vijapur, "Anthelmintic activity of Alocasia indica Schott. rootstocks," International Journal of Drug Development \& Research, vol. 4, pp. 211-214, 2012.

[57] W. A. Mulla, V. S. Thorat, R. V. Patil, and K. B. Burade, 
"Anthelmintic activity of leaves of Alocasia indica Linn," International Journal of Pharmtech Research, vol. 2, pp. 26-30, 2010.

[58] K. G. Brandt, M. M. de C. Antunes, and G. A. P. da Silva, "Acute diarrhea: $\quad$ Evidence-based management," Journal de Pediatria, vol. 91, pp. S36-S43, 2015.

[59] F. Awouters, C J. E. Niemegeers, and P. A. J. Janssen, "Pharmacology of antidiarrheal drugs," Annual Review of Pharmacology and Toxicology, vol.23, pp. 279-301, 1983.

[60] W. A. Mulla, A. R. Chopade, S. B. Bhise, K. B. Burade, and C. C.

[61] Khanwelkar, "Evaluation of antidiarrheal and in vitro antiprotozoal activities of extracts of leaves of Alocasia indica," Research Article of Pharmaceutical Bio-Science, vol. 49, pp. 354-61, 2011. 